\title{
TINJAUAN KRIMINOLOGI TERHADAP SUAMI PELAKU PENGANIAYAAN DALAM RUMAH TANGGA
}

\author{
Lailatus Sururiyah \\ Fakultas Hukum Universitas Muhammadiyah Sumatera Utara \\ E-mail: ailatussururiyah@gmail.com
}

\begin{abstract}
Persecution is to deliberately injure the human body or cause pain as a goal, not as a means of achieving a permissible purpose, such as hitting a child within the boundaries deemed necessary by the child's own parent. The persecution of husbands in the household is included in criminology crimes. It is known that many areas in Indonesia where husbands abuse in the household in this case the persecution to his wife and children. It is understood that the causes of husbands are persecuting the household, namely the wife and child in general, because the husband is often drinking and using drugs, but the whole cause is economic, social, psychological, supporting, and also the cause of the accident. The criminology review of husband's abuse of wife and child when the persecution causes pain, discomfort to the body, the wound of the body. And there must also be elements of the act, either originated from attacks or fights. The consequences of criminal law for husbands who inflict abuse on their wives and children are imposed in accordance with Article 44 of Laws Number 23/2004 on the Elimination of Domestic Violence and also Article 80 of Laws Number 35/2014 on Child Protection.
\end{abstract}

Kata Kunci: Kriminologi, Penganiayaan, Rumah Tangga.

\section{A. Pendahuluan}

Kriminologi merupakan suatu tindakan kejahatan yang dilakukan oleh seseorang, tetapi kriminologi secara teoritis adalah ilmu pengetahuan yang berdasarkan pengalaman yang seperti ilmu pengetahuan lainnya yang sejenis, memperhatikan gejala-gejala dan mencoba menyelidiki sebab-sebab dari gejala tersebut (aetiologi) dengan cara-cara yang ada padanya. Kejahatan adalah pokok penyelidikan kriminologi, yaitu kejahatan yang dilakukan dan orang-orang yang melakukannya, sedangkan segi yuridis dari persoalan tersebut, yaitu perumusan dari pada berbagai kejahatan itu, tidak menarik cakupan perhatian kriminologi .

Arti kejahatan dipandang dari sudut formil (menurut hukum), adalah suatu perbuatan yang oleh masyarakat (dalam hal ini negara) diberi pidana, suatu uraian 
yang tidak memberi penjelasan lebih lanjut seperti juga definisi-definisi yang formil pada umumnya. Ditinjau lebih dalam sampai pada intinya, suatu kejahatan merupakan sebagian dari perbuatan-perbuatan yang bertentangan dengan kesusilaan. Kejahatan harus termasuk di dalamnya, biarpun tidak dapat disangkal bahwa juga ada perbuatan dalam zaman pendudukan dengan kekejamannya sudah banyak dikenal, yang dicap sebagai kejahatan tetapi tidak dirasakan sebagai melanggar kesusilaan, yang dimaksudkan di sini ialah perbuatan yang hanya dipandang jahat menurut bentuknya (Bonger, 1995: 19).

Kejahatan kriminologi ini dapat berupa dari berbagai bentuk termasuk dalam bentuk penganiayaan, baik penganiayaan kepada orang lain maupun penganiayaan kepada keluarga sendiri (isteri dan anak). Kejahatan kriminologi dalam hal ini penganiayaan kepada isteri dan anak dapat terjadi oleh beberapa faktor yang menyebabkan. Di dalam lingkungan rumah tangga baik suami, isteri dan anak, penganiayaan yang sering dilakukan oleh si suami disebut juga dengan kekerasan dalam rumah tangga.

Rumah tangga (keluarga) adalah unit sosial terkecil dalam masyarakat yang berperan dan berpengaruh sangat besar terhadap perkembangan sosial dan perkembangan kepribadian setiap anggota keluarga. Keluarga memerlukan organisasi tersendiri dan perlu kepala rumah tangga sebagai tokoh penting yang memimpin keluarga selain beberapa anggota keluarga lainnya. Anggota keluarga terdiri dari ayah, ibu, dan anak merupakan sebuah satu kesatuan yang memiliki hubungan yang sangat baik. Hubungan baik ini ditandai dengan adanya keserasian dalam hubungan timbal balik antar semua anggota/individu dalam keluarga. Sebuah keluarga disebut harmonis apabila seluruh anggota keluarga merasa bahagia yang ditandai dengan tidak adanya konflik, ketegangan, kekecewaan dan kepuasan terhadap keadaan (fisik, mental, emosi dan sosial) seluruh anggota keluarga, dan keluarga disebut disharmonis apabila terjadi sebaliknya.

Ketegangan maupun konflik antara suami dan istri maupun orang tua dengan anak merupakan hal yang wajar dalam sebuah keluarga atau rumah tangga. Tidak ada rumah tangga yang berjalan tanpa konflik tetapi konflik dalam rumah tangga bukanlah sesuatu yang menakutkan. Hampir semua keluarga pernah 
mengalaminya,yang berbeda adalah cara mengatasi dan menyelesaikan konflik yang terjadi tersebut.

Setiap rumah tangga memiliki cara untuk menyelesaikan masalahnya masing-masing. Apabila masalah diselesaikan secara baik dan sehat, maka setiap anggota keluarga akan mendapatkan pelajaran yang berharga, yaitu menyadari dan mengerti perasaan, kepribadian dan pengendalian emosi tiap anggota keluarga sehingga terwujudlah kebahagiaan dalam keluarga. Penyelesaian konflik secara sehat terjadi jika masing-masing anggota keluarga tidak mengedepankan kepentingan pribadi, mencari akar permasalahan dan membuat solusi yang samasama menguntungkan anggota keluarga melalui komunikasi yang baik dan lancar. Di sisi lain, apabila konflik diselesaikan secara tidak sehat maka konflik akan semakin sering terjadi dalam keluarga.

Penyelesaian masalah ada yang dilakukan dengan marah yang berlebihlebihan, hentakan-hentakan fisik sebagai pelampiasan kemarahan, teriakan dan kata-kata kasar maupun ekspresi wajah menyeramkan. Terkadang muncul perilaku seperti menyerang, memaksa, mengancam atau melakukan kekerasan fisik. Perilaku seperti ini dapat dikatakan pada tindakan kekerasan dalam rumah tangga (KDRT) yang diartikan setiap perbuatan terhadap seseorang terutama perempuan, yang berakibat timbulnya kesengsaraan atau penderitaan secara fisik, seksual, psikologis, dan/atau penelantaran rumah tangga termasuk ancaman untuk melakukan perbuatan, pemaksaan, atau perampasan kemerdekaan secara melawan hukum dalam lingkup rumah tangga, yang merupakan jenis tindak pidana.

Tindak pidana merupakan suatu perbuatan yang dilarang atau diwajibkan undang-undang yang apabila dilakukan atau diabaikan, maka orang yang melakukan atau yang mengabaikan itu diancam dengan pidana. Dalam Kitab Undang-undang Hukum Pidana (KUHP) Buku II mulai Pasal 104 s.d. Pasal 488 mengatur tentang Kejahatan, dan dalam BAB XX tentang Penganiayaan yaitu Pasal 351 s.d. Pasal 358. Tindakan penganiayaan terhadap perempuan banyak terjadi dewasa ini terutama kekerasan dalam rumah tangga atau singkatnya KDRT diatur dalam Undang-undang Nomor 23 Tahun 2004 tentang Penghapusan Kekerasan Dalam Rumah Tangga (UU No. 23 Tahun 2004). 
Keutuhan dan kerukunan rumah tangga yang bahagia, aman, tentram, dan damai merupakan dambaan setiap orang dalam rumah tangga. Negara Republik Indonesia adalah negara yang berdasarkan Ketuhanan Yang Maha Esa dijamin oleh Pasal 29 Undang Undang Dasar Negara Republik Indonesia Tahun 1945 (UUD 145), dengan demikian, setiap orang dalam lingkup rumah tangga dalam melaksanakan hak dan kewajibannya harus didasari oleh agama. Hal ini perlu terus ditumbuhkembangkan dalam rangka membangun keutuhan rumah tangga.

Mewujudkan keutuhan dan kerukunan tersebut, sangat tergantung pada setiap orang dalam lingkup rumah tangga, terutama kadar kualitas perilaku dan pengendalian diri setiap orang dalam lingkup rumah tangga tersebut. Keutuhan dan kerukunan untuk rumah tangga dapat terganggu, jika kualitas dan pengendalian diri tidak dapat dikontrol, yang pada akhirnya dapat terjadi kekerasan dalam rumah tangga, sehingga timbul ketidakamanan atau ketidakadilan terhadap orang yang berada dalam lingkup rumah tangga tersebut.

Kekerasan dalam rumah tangga biasa disebut sebagai "hidden crime" yang telah memakan cukup banyak korban dari berbagai kalangan masyarakat. Hal ini dapat terjadi dalam berbagai bentuk dan disebabkan oleh berbagai faktor. Sebagai akibatnya tidak hanya dialami oleh istri saja, tetapi anak-anak jaga ikut mengalami penderitaan. Untuk mencegah, melindungi korban, dan menindak pelaku kekerasan dalam rumah tangga, negara dan masyarakat wajib melaksanakan pencegahan, perlindungan, dan penindakan pelaku sesuai dengan falsafah Pancasila dan UUD 1945. Negara berpandangan bahwa segala bentuk kekerasan, terutama kekerasan dalam rumah tangga, adalah pelanggaran hak asasi manusia dan kejahatan terhadap martabat kemanusiaan, serta bentuk diskriminasi.

Perkembangan dewasa ini menunjukkan bahwa tindak kekerasan secara fisik, psikis, seksual, dan penelantaran rumah tangga pada kenyataannya terjadi, sehingga dibutuhkan perangkat hukum yang memadai untuk menghapus kekerasan dalam rumah tangga. Pembaruan hukum sangat diperlukan, khususnya tentang perempuan, sehubungan dengan banyaknya kasus kekerasan, terutama kekerasan dalam rumah tangga. Pembaruan hukum tersebut diperlukan karena undang-undang yang ada belum memadai dan tidak sesuai lagi dengan per- 
kembangan hukum masyarakat. Oleh karena itu, diperlukan pengaturan tentang tindak pidana kekerasan dalam rumah tangga secara tersendiri, walaupun secara umum di dalam KUHP telah diatur mengenai penganiayaan dan kesusilaan serta penelantaran orang yang perlu diberikan nafkah dan kehidupan.

Penganiayaan ataupun kekerasan yang dilakukan oleh pihak suami kepada isteri dan anaknya tersebut selain dapat dilihat dari sudut pandang hukum pidana juga dapat dilihat dari sudut pandang tinjauan kriminologi. Itu dimaksudkan agar diketahui bahwa alasan ataupun faktor-faktor yang mengakibatkan suami melakukan penganiayaan/kekerasan kepada orang yang dicintainya dalam hal ini isteri dan anak, serta dikaji juga tentang perbuatan suami itu dalam arah kriminologi termasuk penyimpangan yang seperti apa, karena kasus-kasus penganiayaan ataupun kekerasan dalam rumah tangga ini tidak hanya terjadi di satu tempat atau di satu keluarga saja, melainkan juga terjadi di berbagai tempat atau pun di banyak lingkungan keluarga. Kasus ini tidak boleh hanya dipandang dari sudut hukum pidana melainkan juga dari sudut gejala kejahatan kriminologi, karena penganiayaan/kekerasan dalam rumah tangga yang dilakukan suami ini sudah menjangkit di banyak tempat.

\section{B. Kriminologi dan Jenis Kejahatan Kriminologi}

Kriminologi merupakan ilmu pengetahuan yang mempelajari tentang kejahatan. Istilah kriminologi yang ditemukan oleh P. Topinard (1830-1911) seorang ahli antropologi Perancis, secara harfiah berasal dari kata crimen yang berarti kejahatan atau penjahat dan logos yang berarti ilmu pengetahuan, maka kriminologi dapat berarti ilmu tentang kejahatan atau penjahat. Beberapa sarjana memberikan definisi berbeda mengenai kriminologi ini (Topo Santoso dan Eva Achjani Zulfa, 2010: 9), bahkan kriminologi berbeda dengan hukum pidana.

Hukum pidana sudah ada dengan sanksi yang berat, tetapi mengapa kejahatan tetap terjadi? Pada dasarnya para pembentuk hukum pidana mengharapkan bahwa pada suatu saat kejahatan akan lenyap dan disinilah kriminologi memegang peran penting. Adalah suatu kenyataan bahwa hukum pidana tidaklah efektif. Thomas More membuktikan bahwa sanksi yang berat bukanlah faktor 
yang utama untuk memacu efektivitas dari hukum pidana. Adalah suatu kenyataan pada zamannya para pencopet tetap bereaksi di tengah kerumunan masyarakat yang tengan menyaksikan suatu eksekusi hukuman mati pada 24 penjahat. Suatu gambaran bahwa orang menjadi masa bodoh dengan hukum pidana.

Hukum pidana pada abad ke-16 hingga abad ke-18 semata-mata dijalankan untuk menakut-nakuti dengan jalan menjatuhkan hukuman yang sangat berat. Hukuman mati yang dilakukan dengan berbagai cara, umumnya dilakukan dengan cara yang mengerikan dan hukuman badan merupakan hal yang biasa dijatuhkan terhadap kejahatan yang terjadi di masyarakat. Hal yang menjadi tujuan pada waktu itu adalah bagaimana agar masyarakat pada umumnya dapat terlindungi dari kejahatan. Hukum acara pidana, hal yang sama pun terjadi. Bonger melukiskan bahwa terdakwa diperlakukan seperti barang untuk diperiksa. Pemeriksaan dilakukan secara rahasia dan pembuktian digantungkan kepada kemauan si pemeriksa (Topo Santoso dan Eva Achjani Zulfa, 2010: 4-5). Kriminologi termasuk cabang ilmu yang baru, berbeda dengan hukum pidana yang muncul begitu manusia bermasyarakat.

Kriminologi baru berkembang tahun 1850 bersama-sama sosiologi, antropologi dan psikologi, cabang-cabang ilmu yang mempelajari gejala/tingkah laku manusia dalam masyarakat. Harus diingat pula manusia adalah makhluk yang paling berkembang di antara makhluk lain (Topo Santoso dan Eva Achjani Zulfa, 2010: 3), oleh karena itu kriminologi ini sangat berpengaruh terhadap pola tingkah laku manusia dalam melakukan suatu perbuatan. Salah satu bentuk pembahasan kriminologi adalah kejahatan. Kejahatan merupakan suatu fenomena yang kompleks yang dapat dipahami dari berbagai sisi yang berbeda. Hal ini yang menyebabkan dalam keseharian orang dapat menangkap berbagai komentar tentang suatu peristiwa kejahatan yang berbeda satu dengan yang lain. Dalam pengalaman, ternyata tak mudah untuk memahami kejahatan itu sendiri.

Bonger dalam buku Topo Santoso dan Eva Achjani Zulfa (2010: 9), memberikan definisi kriminologi sebagai ilmu pengetahuan yang bertujuan menyelidiki gejala kehatan seluas-luasnya. Melalui definisi ini, Bonger lalu membagi kriminologi ini menjadi kriminologi murni yang mencakup: 
1. Antropologi kriminil, adalah ilmu pengetahuan tentang manusia yang jahat (somatic). Ilmu pengetahuan ini memberikan jawaban atas pertanyaan tentang orang jahat dalam tubuhnya mempunyai tanda-tanda seperti apa, apakah ada hubungan antara suku bangsa dengan kejahatan dan seterusnya;

2. Sosiologi kriminil, adalah ilmu pengetahuan tentang kejahatan sebagai suatu gejala masyarakat. Pokok persoalan yang dijawab oleh bidang ilmu ini adalah letak sebab-sebab kejahatan dalam masyarakat;

3. Psikologi kriminil, adalah ilmu pengetahuan tentang penjahat yang dilihat dari sudut jiwanya;

4. Prikopatologi dan europatologi kriminil; dan

5. Penology, ada ilmu tentang tumbuh dan berkembangnya hukuman.

Selain itu menurut Topo Santoso dan Eva Achjani Zulfa (2010: 9-10), terdapat kriminologi terapan, berupa:

1. Higiene kriminil, adalah usaha yang bertujuan untuk mencegah terjadinya kejahatan. Misalnya: usaha-usaha yang dilakukan oleh pemerintah untuk menerapkan undang-undang, sistem jaminan hidup dan kesejahteraan yang dilakukan semata-mata untuk mencegah terjadinya kejahatan;

2. Politik kriminil, adalah usaha penanggulangan kejahatan dimana suatu kejahatan telah terjadi. Di sini dilihat sebab-sebab seorang melakukan kejahatan. Bila disebabkan oleh faktor ekonomi, maka usaha yang dilakukan adalah meningkatkan keterampilan atau membuka lapangan kerja. Jadi tidak semata-mata dengan penjatuhan sanksi; dan

3. Kriminalistik (police scientific), adalah ilmu tentang pelaksanaan penyidikan teknik kejahatan dan pengusutan kejahatan.

\section{Tindak Pidana Penganiayaan dan Jenis-jenis Penganiayaan}

KUHP adalah sumber pokok hukum pidana materil, memuat tentang aturan umum hukum pidana dan rumusan-rumusan tindak pidana tertentu. Mengenai aturan umum dimuat dalam Buku I, sedangkan tindak pidana tertentu dimuat dalam Buku II dan III. Aturan umum memuat asas-asas umum mengenai berbagai hal atau bidang dalam hukum pidana, misalnya: tentang batas-batas 
berlakunya hukum pidana, tentang pidana dan hal-hal yang meniadakan, mengurangi, serta memberatkan pidana, tentang percobaan, tentang perbarengan, tentang penyertaan dan lain-lain. Aturan umum hukum pidana ini berlaku tidak saja bagi tindak pidana yang ada dalam Buku II dan Buku III KUHP, melainkan juga terhadap tindak pidana yang ada di luar KUHP, apabila dalam undang-undang lain itu tidak ditentukan lain (Pasal 103 KUHP). Tindak pidana yang dimuat dalam Buku II dan III tadi, berupa rumusan tentang perbuatan-perbuatan tertentu (aktif maupun pasif) yang dilarang untuk dilakukan oleh orang yang disertai ancaman pidana tertentu bagi setiap orang yang melakukan perbuatan yang menjadi larangan itu.

Adanya ancaman pidana terhadap orang yang melanggar aturan mengenai larangan melakukan perbuatan yang dirumuskan dalam undang-undang adalah sebagai suatu ciri dari suatu tindak pidana tertentu, yang membedakan dengan aturan mengenai larangan perbuatan lain yang bukan merupakan tindak pidana. Kejahatan yang dimuat dalam Buku II, pada kenyataannya mengandung sanksi pidana yang lebih berat daripada pelanggaran di tempatkan dalam golongangolongan tertentu berdasarkan kesamaan sifatnya, yang salah satu sifat yang sama itu adalah berdasarkan suatu kepentingan hukum (rechtsbelang) yang dibahayakan/dilanggar (Adami Chazawi, 2013: 1-2). Kejahatan yang dapat membahayakan atau melanggar itu termasuk kejahatan terhadap tubuh manusia. Kejahatan terhadap tubuh manusia itu ialah termasuk di dalamnya penganiayaan, oleh karena itu tindak pidana penganiayaan/kejahatan terhadap tubuh manusia tersebut juga di atur dalam KUHP.

Dibentuknya kejahatan terhadap tubuh manusia (misdrijven tegen bet liif) ini ditujukan bagi perlindungan kepentingan hukum atas tubuh dari perbuatanperbuatan berupa penyerangan atas tubuh atau bagian dari tubuh yang mengakibatkan rasa sakit atau luka, bahkan karena luka yang sedemikian rupa pada tubuh dapat menimbulkan kematian. Terdapat beberapa macam bentuk kejahatan terhadap tubuh manusia, hal tersebut sesuai dengan unsur-unsur yang ditimbulkan. Atas dasar unsur kesalahannya kejahatan terhadap tubuh ada 2 (dua) jenis, yaitu: 
1. Kejahatan terhadap tubuh yang dilakukan dengan sengaja. Kejahatan yang dimaksudkan ini diberi kualifikasi sebagai penganiayaan (misbandeling), dimuat dalam Bab XX Buku II, Pasal 352 s.d. dengan Pasal 358 KUHP; dan

2. Kejahatan terhadap tubuh karena kelalaian, dimuat dalam Pasal 360 Bab XXI KUHP, yang dikenal dengan kualifikasi karena lalai menyebabkan orang lain luka.

Kejahatan terhadap tubuh yang dilakukan dengan sengaja (penganiayaan) dapat dibedakan menjadi 6 (enam) jenis, yaitu:

1. Penganiayaan biasa ( Pasal $351 \mathrm{KUHP}$ );

2. Penganiayaan ringan (Pasal $352 \mathrm{KUHP}$ );

3. Penganiayaan berencana (Pasal 353 KUHP);

4. Penganiayaan berat (Pasal 354 KUHP);

5. Penganiayaan berat berencana (Pasal 355 KUHP); dan

6. Penganiayaan dengan cara dan terhdap orang-orang yang berkualitas tertentu yang memberatkan (Pasal 356 KUHP).

Jenis-jenis penganiayaan tersebut dikualifikasikan berdasarkan luka yang diakibatkan dari penganiayaan itu, dan walaupun istilah luka ringan tidak dikenal dalam rumusan bentuk-bentuk penganiayaan, karena dengan adanya istilah luka berat dalam Pasal 351 ayat (2) KUHP, begitu juga dalam Pasal 353 ayat (2) jo Pasal 90, tetapi luka ringan dapat diartikan sebagai suatu luka yang bukan luka berat sebagaimana yang dimaksudkan oleh Pasal 90, suatu pengertian kebalikan dari luka berat (Adami Chazawi, 2011: 16-17). Pemberian kualifikasi sebagai penganiyaan biasa yang dapat disebut juga dengan penganiayaan bentuk pokok atau bentuk standard terhadap ketentuan Pasal 351 KUHP sungguh tepat, setidaktidaknya untuk membedakannya dengan bentuk-bentuk penganiayaan lainnya.

Dilihat dari sudut cara pembentuk undang-undang dalam merumuskan penganiayaan, kejahatan ini mempunyai suatu keistimewaan. Apabila pada rumusan kejahatan-kejahatan lain, pembentuk undang-undang dalam membuat rumusannya adalah dengan menyebut unsur tingkah laku dan unsur-unsur lainnya, seperti kesalahan, melawan hukum atau unsur mengenai obyeknya, mengenai cara melakukannya dan sebagainya, tetapi pada kejahatan sebagaimana tersebut pada 
Pasal 352 ayat (1) KUHP yang diberi kualifikasi penganiayaan ini, dirumuskan dengan sangat singkat, yaitu dengan menyebut kualifikasinya sebagai penganiayaan (misbandeling) sama dengan judul dari Bab XX, dan menyebutkan ancaman pidananya (Adami Chazawi, 2013: 7-8).

\section{Hukum Kekerasan dalam Rumah Tangga}

Kekerasan dalam rumah tangga (KDRT) yang dulu dianggap mitos dan persoalan pribadi (private), kini menjadi fakta dan realita dalam kehidupan rumah tangga. Dengan berlakunya UU No. 23 Tahun 2004, maka persoalan KDRT ini menjadi domain publik. Sebagian besar korban KDRT adalah kaum perempuan dan pelakunya adalah suami, walaupun ada juga korban justru sebaliknya, atau orang-orang yang tersubordinasi di dalam rumah tangga itu. Pelaku atau korban KDRT adalah orang yang mempunyai hubungan darah, perkawinan, persusuan, pengasuhan, perwalian dengan suami, dan anak bahkan pembatu rumah tangga, tinggal di rumah tersebut. Ironisnya kasus KDRT sering ditutup-tutupi oleh si korban karena terpaut dengan struktur budaya, agama dan sistem hukum yang belum dipahami. Padahal perlindungan oleh negara dan masyarakat bertujuan untuk memberi rasa aman terhadap korban serta menindak pelakunya.

UU No. 23 Tahun 2004, secara substanstif memperluas institusi dan lembaga pemberi perlindungan agar mudah diakses oleh korban KDRT, yaitu pihak keluarga, advokat, lembaga sosial, kepolisian, kejaksaan, pengadilan atau pihak lainnya, baik perlindungan sementara, maupun berdasarkan penetapan pengadilan. Di sini terlihat, bahwa institusi dan lembaga pemberi perlindungan itu tidak terbatas hanya lembaga penegak hukum, tetapi termasuk juga lembaga sosial bahkan disebutkan pihak lainnya, sehingga dapat memaksimalkan dalam membantu perlindungan (korban) kekerasan dalam rumah tangga.

Aturan-aturan ataupun dasar-dasar hukum yang berhubungan/terkait dengan perlindungan isteri dan anak dapat didapat pada umumnya ada juga di KUHP, secara khususnya terdapat dalam UU No. 23 Tahun 2004 dan UndangUndang Nomor 35 Tahun 2014 tentang Perubahan Atas Undang-undang Nomor 23 Tahun 2002 tentang Perlindungan Anak (UU No. 35 Tahun 2014). Undang- 
undang yang disebutkan ini hampir seluruhnya mengkoordinir ataupun melindungi tentang hak-hak isteri dan anak.

Menurut Pasal 1 angka 16 UU No. 35 Tahun 2014 disebutkan bahwa pengertian "kekerasan adalah setiap perbuatan terhadap anak yang berakibat timbulnya kesengsaraan atau penderitaan secara fisik, psikis, seksual dan/atau penelantaran, termasuk ancaman untuk melakukan perbuatan, pemaksaan, atau perampasan kemerdekaan secara melawan hukum", sedangkan dalam Pasal 1 angka 1 UU No. 23 Tahun 2004. mengartikan: "kekerasan dalam rumah tangga adalah setiap perbuatan terhadap seseorang terutama perempuan yang berakibat timbulnya kesengsaraan atau penderitaan secara fisik, seksual, psikologis, dan/atau penelantaran rumah tangga termasuk ancaman untuk melakukan perbuatan, pemaksaan, atau perampasan kemerdekaan secara melawan hukum dalam lingkup rumah tangga".

Selanjutnya dalam Pasal 1 angka 3 UU No. 23 Tahun 2004 menjelaskan pengertian "korban adalah orang yang mengalami kekerasan dan/atau ancaman kekerasan dalam lingkup rumah tangga". Berarti berdasarkan penjelasan pasal ini menerangkan bahwa korban dalam kekerasan dalam rumah tangga ini dapat saja ibu, bapak, suami, isteri ataupun anak, tetapi dalam faktanya bahwa kebanyakan yang menjadi korban kekerasan dalam rumah tangga yaitu pihak isteri dan anak, dan pelakunya adalah suami sendiri.

Pasal 89 KUHP menjelaskan bahwa: "yang disamakan melakukan kekerasan itu, membuat orang jadi pingsan atau tidak berdaya lagi (lemah)". Melakukan kekerasan artinya mempergunakan tenaga atau kekuatan jasmani tidak kecil secara yang tidak sah, misalnya memukul dengan tangan atau dengan segala macam senjata, menyepak, menendang dan sebagainya, dan yang disamakan dengan melakukan kekerasan menurut pasal ini ialah membuat orang jadi pingsan atau tidak berdaya.

Pingsan artinya tidak ingat atau tidak sadar akan dirinya, umpamanya memberi minum racun kecubung atau lain-lain obat, sehingga orangnya tidak ingat lagi. Orang yang pingsan itu tidak dapat mengetahui apa yang terjadi akan dirinya. Tidak berdaya artinya tidak mempunyai kekuatan atau tenaga sama 
sekali, sehingga tidak dapat mengadakan perlawanan sedikitpun, misalnya mengikat dengan tali kaki dan tangannya, mengurung dalam kamar, memberikan suntikan, sehingga orang itu lumpuh.

Orang yang tidak berdaya itu masih dapat mengetahui apa yang terjadi atas dirinya. Mengancam orang yang membuat orang itu pingsan atau tidak berdaya itu tidak boleh disamakan dengan mengancam dengan kekerasan, sebab dalam pasal ini hanya mengatakan tentang melakukan kekerasan, tidak membicarakan tentang kekerasan atau ancaman kekerasan (Soesilo, 1995: 98), sehingga pada dasarnya yang dapat dikenakan sebuah sanksi pidana dari tindak pidana kekerasan itu ialah pelaku yang memang benar-benar melakukan penganiayaan/kekerasan itu sendiri, sedangkan orang yang hanya melakukan pengancaman untuk melakukan penganiayaan tidak dikenakan sanksi itu.

Ketentuan pidana terhadap pelaku kekerasan dalam rumah tangga diatur dalam Pasal 44 sampai dengan Pasal 53 UU No. 23 Tahun 2004. Sanksi pidana terhadap kekerasan dalam rumah tangga secara umum ada juga diatur beberapa dalam KUHP selain UU No. 23 Tahun 2004. Kekerasan ini dapat termasuk dalam jenis penganiayaan, dan beberapa pasal dimaksud yaitu Pasal 351, Pasal 352 dan Pasal 352 KUHP. Pasal-pasal dalam KUHP ini menyebutkan sanksi pidana bagi para pelaku kekerasan ataupun penganiayaan, dan itu juga berlaku bagi perlaku kekerasan dalam rumah tangga ataupun yang dilakukan seorang suami kepada istrinya/seorang ayah kepada anaknya.

\section{E. Unsur Kriminologi Penganiayaan yang Dilakukan Suami dalam Rumah Tangga}

Kriminologi adalah kumpulan ilmu pengetahuan tentang kejahatan yang bertujuan untuk memperoleh pengetahuan dan pengertian tentang gejala kejahatan dengan jalan mempelajari dan menganalisa secara ilmiah keterangan-keterangan, keseragaman-keseragaman, pola-pola dan faktor-faktor kausal yang berhubungan dengan kejahatan, pelaku kejahatan serta reaksi masyarakat terhadap keduanya, jadi obyek studinya menurut Topo Santoso dan Eva Achjani Zulfa (2010: 12) mencakup: 
1. Perbuatan yang disebut dengan kejahatan;

2. Pelaku kejahatan, dan

3. Reaksi masyarakat yang ditujukan baik terhadap perbautan maupun terhadap pelakunya.

Ketiga hal tersebut membuktikan bahwa perlakuan aniaya ataupun seseorang yang melakukan penganiayaan kepada orang yang lain termasuk di dalam pelaku kejahatan kriminologi. Penganiayaan dilihat dari sudut pandang kriminologi tentunya termasuk dalam kejahatan. Oleh sebab itu, penganiayaan yang dilakukan suami kepada istri dan anaknya ini dapatlah dilihat dari sudut pandang kriminologi, sehingga dapat dilihat unsur-unsur kriminologi apa saja yang termasuk dalam perbuatan penganiayaan oleh suami kepada istri dan anak.

Suami berarti laki-laki atau pria yang telah kawin, beristeri (Muhammad Ali, 2000: 463), sekaligus kepala dalam rumah tangga. Sebagai kepala rumah tangga suami harus melindungi istri dan anaknya, bukanlah melakukan tindakan kriminologi seperti penganiayaan ini. Banyak bentuk kekerasan dalam rumah tangga, sebagaimana yang nyata-nyata dirasakan oleh kaum perempuan atau anak. Apabila dilihat dari bentuknya, dapat dibagi 2 (dua) bentuk, yaitu kekerasan terhadap psikis dan kekerasan terhadap fisik (Mustofa Hasan, 2011: 363).

Menurut doktrin/ilmu pengetahuan hukum pidana, berdasarkan sejarah pembentukan dari pasal yang bersangkutan sebagaimana yang diterangkan, penganiayaan diartikan sebagai perbuatan yang dilakukan dengan sengaja untuk menimbulkan rasa sakit atau luka pada tubuh orang lain. Ternyata dalam doktrin penganiayaan diberi arti yang tidak jauh berbeda dengan pengertian yang dirumuskan pertama pada rancangan dari pasal yang bersangkutan yang sudah diterangkan sebelumnya. Menurut doktrin penganiayaan mempunyai unsur-unsur sebagai berikut:

1. Adanya kesengajaan;

2. Adanya perbuatan; dan

3. Adanya akibat perbuatan (yang dituju), yakni:

a. Rasa sakit pada tubuh; atau

b. Luka pada tubuh. 
Unsur yang pertama adalah berupa unsur subyektif (kesalahan), unsur kedua dan ketiga berupa unsur obyektif. Kesengajaan di sini berupa sebagai maksud atau opzet als oogmerk, selain harus ditujukan pada perbuatannya, juga harus ditujukan pada akibatnya. Berdasarkan penjelasan tersebut, maka perbuatan seperti orang tua (ayah) yang memukul anak adalah termasuk juga pada pengertian penganiayaan (Mustofa Hasan, 2011: 10-11).

Unsur-unsur demikian jika ada juga pada penganiayaan yang dilakukan oleh suami kepada istri dan anaknya, maka penganiayaan yang dilakukan tersebut sudah terpenuhilah unsur-unsur kriminologi di dalamnya. Dengan demikian penganiayaan suami kepada istri dan anak itu termasuk dalam kejahatan kriminologi, yang pelakunya adalah si suami, karena unsur-unsur untuk dikatakan kejahatan kriminologi itu sendiri sudah terpenuhi.

Unsur-unsur kriminologi itu juga dapat muncul akibat tidak dipenuhinya hak-hak istri dan anak dan suami tidak memenuhi kewajibannya. Hak merupakan kemaslahatan yang diperoleh secara syara, hak juga dapat diartikan yaitu sesuatu yang melekat pada setiap manusia, yang tanpanya manusia tersebut mustahil dapat hidup dan dikatakan sebagai manusia, sedangkan kewajiban berarti sesuatu yang apabila dilaksanakan mendapat pahala dan berdosa jika ditinggalkan. Kewajiban di sini selanjutnya ialah sesuatu yang wajib dilakukan oleh seseorang dalam waktu, kondisi dan keadaan tertetu dengan ketentuan apabila tidak dilaksanakan akan mendapatkan sanksi (Muhammad Yusuf Siregar, 2015: 81). Bagi yang tidak memenuhi kewajibannya dan tidak memberikan hak-hak kepada orang lain dalam hal ini istri dan anak, maka hal tersebut juga dapat dikatakan suatu perbuatan kejahatan kriminologi. Seperti halnya kewajiban suami untuk menjaga istri dan anaknya, tetapi yang dilakukan suami kebalikannya adalah mencelakakan/ menganiaya istri dan anak, dengan begitu akan dikenakan sanksi karena unsur dari kejahatan kriminologi itu telah terpenuhi. Tentunya jika penganiayaan tersebut memang terbukti dan meninggalkan bekas luka pada fisik ataupun rasa sakit.

Unsur-unsur terpenuhinya kejahatan kriminologi itu dapat dilihat dari 2 (dua) hal, yaitu dari spritualisme dan juga dari naturalisme. Termasuk juga untuk melihat memang terpenuhinya unsur kriminologi dalam penganiayaan yang 
dilakukan suami kepada istri dan anaknya. Dapat dilihat dari kedua sudut pandang tersebut. Dengan mengetahui kedua hal tersebut, maka dapat dilihat penganiayaan itu memang berdasarkan unsur kriminologi ataupun tidak.

Penjelasan tentang kejahatan, menurut spiritualisme memiliki perbedaan mendasar dengan metode penjelasan kriminologi yang ada saat ini. Berbeda dengan teori-teori saat ini, penjelasan spiritualisme memfokuskan perhatiannya pada perbedaan antara kebaikan yang datang dari tuhan atau dewa dan keburukan yang datang dari setan. Seseorang yang telah melakukan suatu kejahatan dipandang sebagai orang yang telah terkena bujukan setan. Landasan pemikiran yang paling rasional dari perkembang ini adalah bahwa pada periode sebelumnya kejahatan dianggap sebagai permasalahan antara korban dan keluarga korban dengan pelaku dan keluarganya. Akibatnya adalah konflik berkepanjangan antar keluarga yang dapat mengakibatkan musnahnya keluarga tersebut. Juga menjadi suatu masalah adalah bahwa pelaku kejahatan yang berasal dari keluarga yang memiliki posisi kuat dalam masyarakat tidak akan dapat dihukum (Muhammad Yusuf Siregar, 2015: 20).

Metode untuk membuktikan kesalahan seseorang dalam masyarakat primitif memiliki banyak model, walaupun dalam kenyataan di masyarakat, dapat dilihat bahwa penjelasan spiritual ini ada dan berlaku dalam berbagai bentuk dan tingkat kebudayaan, tetapi aliran ini memiliki kelemahan. Kelemahannya itu terletak pada penjelasan yang tidak dapat dibuktikan secara ilmiah.

Selanjutnya yaitu naturalisme, merupakan model pendekatan lain yang sudah ada sejak berabad-abad yang lalu. Perkembangan paham rasionalisme yang muncul dari perkembangan ilmu alam setelah abad pertengahan menyebabkan manusia mencari model penjelasan lain yang lebih rasional dan mampu dibuktikan secara ilmiah. Dalam perjalanan sejarah kedua model penjelasan ini beriringan meski bertolak belakang. Lahirnya rasionalisme menjadikan pendekatan ini mendominasi pemikiran tentang kejahatan pada abad selanjutnya (Muhammad Yusuf Siregar, 2015: 21). Penganiayaan dapat dirasionalkan menjadi salah satu bentuk kejahatan kriminologi melalui kedua pendekatan tersebut, sehingga ditemukan unsur-unsur kejahatan kriminologi dalam perbuatan peng- 
aniayaan itu, dan tentunya khusus pada penganiayaan yang dilakukan suami kepada istri dan anak

obyek tinjauan kriminologi ditekankan pada gejala kejahatan seluasluasnya dalam artian mempelajari kejahatan dan penjahat, usaha-usaha pencegahan penanggulangan kajahatan, serta perlakuan terhadap penjahat, sedangkan subjek kriminologi adalah anggota dan kelompok masyarakat secara keseluruhan sebagai suatu kelompok sosial yang memiliki gejala-gejala sosial sebagai suatu sistem yang termasuk di dalamnya gejala kejahatan yang tidak terpisahkan.

Tinjauan kriminologi penganiayaan suami terhadap istri dan anak yang terjadi di lingkup rumah tangga dan pelaku kejahatan kriminologi yang tidak lain adalah si suami terhadapnya berlaku psikologi kriminal dan sosiologi kriminal. Psikologi kriminal mencari sebab-sebab dari faktor psikis termasuk agak baru, seperti halnya para positivis pada umumnya, usaha untuk mencari ciri-ciri psikis kepada para penjahat didasarkan anggapan bahwa penjahat merupakan orangorang yang mempunyai ciri-ciri psikis yang berbeda dengan orang-orang yang bukan penjahat, dari ciri-ciri psikis tersebut terletak pada intelegensinya yang rendah.

Psikologi kriminal adalah mempelajari ciri-ciri psikis dari para pelaku kejahatan yang sehat, artinya sehat dalam pengertian psikologis. Mengingat konsep tentang jiwa yang sehat sulit dirumuskan, dan kalaupun ada maka perumusannya sangat luas dan masih belum adanya perundang-undangan yang mewajibkan para hakim untuk melakukan pemeriksaan psikologis/psikiatris, sehingga masih sepenuhnya diserahkan kepada psikolog. Dalam konteks lain, ada juga yang dinamakan sosilogi kriminal. Obyek utama sosiologi kriminal adalah mempelajari hubungan antara masyarakat dengan anggotanya, antara kelompok baik karena hubungan tempat atau etnis dengan anggotanya antara kelompok dengan kelompok sepanjang hubungan itu dapat menimbulkan kejahatan (Muhammad Yusuf Siregar, 2015: 21).

Terhadap pembahasan mengenai asal-usul tingkah laku kriminal dan dalam pertimbangan mengenai faktor mana yang memegang peran, utamanya di antara faktor keturunan atau faktor lingkungan, kriminolog tersebut menarik 
kesimpulan, bahwa kriminalitas manusia normal adalah akibat, baik dari faktor keturunan maupun dari faktor lingkungan, di mana kadang-kadang dari faktor keturunan dan kadang-kadang pula faktor lingkungan memegang peran utama, dan di mana kedua faktor itu juga dapat saling mempengaruhi.

Harus dikaji secara lebih mendalam dengan menemukan unsur dalam tinjauan kriminologi dalam menentukan kejahatan kriminologi penganiayaan yang dilakukan suami kepada anak dan istri dalam rumah tangga. Dalam aspek kriminologi unsur penganiayaan dapat dilihat dari berbagai sudut pandang. Penganiayaan itu juga mempunyai 2 (dua) unsur utama, yaitu unsur obyektif dan juga unsur subyektif. Unsur-unsur obyektif yaitu:

1. perbuatan turut serta;

2. dalam penyerangan atau dalam perkelahian;

3. dimana terlibat beberapa orang; dan

4. menimbulkan akibat:

a. ada yang luka berat;dan

b. ada yang mati.

Sedangkan unsur subyektif ialah dengan sengaja. Berdasarkan unsur-unsurnya, kejahatan hanya mungkin terjadi jika adanya penyerangan dan perkelahian di mana terlibat beberapa orang. Orang yang dipersalahkan adalah bagi mereka yang dengan sengaja turut serta dalam penyerangan atau perkelahian itu, dan bukan bagi orang yang menyerang atau yang berkelahi, jika penyerangan atau perkelahian itu menimbulkan adanya orang luka berat dan adanya orang mati.

Pada kasus penganiayaan yang dilakukan suami kepada anak dan istrinya, dapat berawal dari perkelahian di antara suami dan istri ataupun dapat berupa penyerangan sepihak oleh suami, baik penyerangan ataupun perkelahian dapat memicu timbulnya perbuatan penganiayaan yang dilakukan oleh suami tersebut. Di antara penyerangan ataupun perkelahian yang mengakibatkan terjadinya penganiayaan oleh suami, tergolong perbuatan kejahatan kriminologi, karena merugikan pihak anak ataupun istri.

Terkait faktor-faktor suami melakukan penganiayaan kepada istri dan anak, yang dalam kejahatan ini dicantumkan unsur kesengajaan. Ada keterangan 
yang menyatakan bahwa setiap unsur kesengajaan yang dicantumkan dalam rumusan tindak pidana, berarti unsur kesengajaan itu ditujukan/meliputi unsurunsur yang ada di belakang perkataan/unsur kesengajaan itu, dan jika dihubungkan dengan unsur-unsur yang ada dalam Pasal 358 KUHP, maka kesengajaan itu ditujukan pada unsur-unsur perbuatan turut serta, dalam penyerangan atau dalam perkelahian, yang melibatkan beberapa orang. Artinya petindak menghendaki untuk melakukan perbuatan turut serta, dan pelaku mengetahui bahwa turut sertanya itu adalah dalam penyerangan atau perkelahian, dan pelaku mengerti bahwa dalam penyerangan atau perkelahian itu terlibat beberapa orang.

Kesengajaan itu tidak perlu ditujukan pada akibat adanya orang luka berat atau adanya orang mati. Unsur akibat ini adalah berupa unsur syarat tambahan untuk dapat dipidananya orang yang melakukan penyerangan atau perkelahian. Akibat ini tidak disyaratkan harus timbul dari perbuatan itu, tetapi dari penyerangan atau perkelahian itu sendiri. korban yang harus menderita akibat luka berat atau kematian itu. Pihak yang menderita luka berat atau kematian itu adalah pada pihak yang diserang atau pihak yang berkelahi, tetapi dapat juga pada pihak orang lain yang tidak terlibat/pihak ketiga yang mungkin berusaha memisah penyerangan atau perkelahian (Muhammad Yusuf Siregar, 2015: 49-50), sehingga unsur-unsur kriminologi dalam penganiayaan oleh suami kepada anak dan istri termasuk di dalamnya adanya penyerangan ataupun perkelahian.

Unsur kriminologi penganiayaan suami kepada istri dan anaknya dapat dilihat dari suami yang melakukan perbuatan itu pada saat setelah meminum minuman keras/memabukkan dan juga ada setelah memakai narkoba. Perbuatan kriminologi sebelumnya itu memicu suami melakukan penganiayaan, serta terkadang pihak suami/ayah terkadang tidak mengetahui telah melakukan kekerasan kepada istri dan/atau anaknya. Hal itu membuktikan suami tesebut telah sering melakukan penganiayaan/pemukulan itu kepada istri dan/atau anak, lamakelamaan menjadi suatu kebiasaan oleh suami. Terhadap penganiayaan yang telah menjadi kebiasaan oleh suami itu, cukuplah unsur kriminologi terpenuhi dalam penganiayaan itu, sama seperti penyakit kriminologi bagi suami melakukan penganiayaan tanpa merasakan salah ataupun penyesalan. 
Unsur-unsur kriminologi penganiayaan yang dilakukan suami kepada istri dan anak mengaitkan banyak hal. Seperti yang sudah dijelaskan sebelumnya, unsur-unsur itu ada unsur kesengajaan ataupun tidak penganiayaan itu tetap termasuk kejahatan kriminologi, apabila menimbulkan rasa sakit, tidak enak pada tubuh, lukanya tubuh (baik luka ringan atau luka berat). Harus ada juga unsur perbuatan, baik berawal dari penyerangan ataupun perkelahian, jika semua hal tersebut telah terpenuhi pada saat suami melakukan penganiayaan kepada istri dan anaknya, maka lengkaplah unsur kejahatan kriminologi suami.

Melalui tinjauan kriminologi didapati bahwa kejahatan penganiayaan yang dilakukan suami kepada istri dan anak dalam rumah tangga dapat dibedakan menjadi 2 (dua) kelompok, yaitu:

1. Kejahatan penganiayaan ringan, yaitu dikarenakan beberapa penganiayaan yang dilakukan suami kepada istri dan anaknya hanya atas dasar ketidaksengajaan dan juga hanya karena batas emosi/kemarahan sesaat, serta penganiayaan yang dilakukan suami bukan suatu bentuk kebencian kepada istri dan anaknya, melainkan hanya pelampiasan sesaat atas hal (kejahatan) yang telah dilakukannya sebelumnya, dan kemudian penganiayaan itu hanya menimbulkan luka ringan, yang tidak mengakibatkan penyakit yang serius kepada istri atau anaknya.

2. Kejahatan penganiayaan berat, yaitu dikarenakan penganiayaan yang dilakukan suami kepada anak dan istrinya sendiri, perbuatan penganiayaan yang dilakukan kepada anak dan istrinya sendiri sisi kejahatan yang lebih dalam. Selain itu, penganiayaan memang telah dilakukan berulang kali, bahkan sering dilakukan oleh suami kepada si anak terutama istri, sehingga mengakibatkan kejahatan penganiayaan menjadi suatu kebiasaan. Penganiayaan ini dari segi tinjauan kriminologi dikatakan sebagai kejahatan berat.

Kedua jenis kejahatan kriminologi itu dikelompokkan dengan alasan sebab-sebab serta akibat-akibat yang ditimbulkan dari kejahatan kriminologi itu sendiri, serta juga dilihat dari objek pelaku dan juga pihak yang menjadi korban dari kejahatan kriminologi. Tinjauan kriminologi melihat dari segala sudut pandang terhadap kejahatan-kejahatan kriminologi yang dimaksud, termasuk 
intensitas kejahatan itu dilakukan, maka kejahatan kriminologi penganiayaan yang dilakukan suami kepada istri dan anak di dalam rumah tangga meliputi 2 (dua) jenis kejahatan penganiayaan di atas.

Berdasarkan beberapa tinjauan kriminologi, juga ditemukan bahwa suami sebagai pelaku kejahatan kriminilogi (penganiayaan) kepada istri dan anak di dalam rumah tangga termasuk dalam 3 (tiga) macam bentuk kejahatan, yaitu:

1. The casual offender, yaitu seorang melakukan pelanggaran disebabkan oleh kelalaiannya dan dilakukan secara kebetulan. Perbuatan tersebut sebetulnya belum dapat dikategorikan sebagai penjahat, karena perbuatannya dilakukan secara tidak disadari dan atau terpaksa.

2. The habitual criminal, yaitu pelaku kejahatan yang melakukan kejahatan karena kebiasaannya. Perbuatan itu dilakukan terus menerus, karena perbuatannya dianggap menjadi bagian dari kebiasaan hidupnya.

3. The normalicious criminal, bahwa pada tipe ini melakukan kejahatan yang dianggap benar menurut dirinya, tetapi orang lain menganggapnya tidak benar. Hal ini disebabkan adanya kelompok tertentu menganggap bahwa perbuatan tersebut benar, tetapi kelompok lain menganggapnya sebagai perbuatan yang tidak benar. Jadi orang ini melakukan kejahatan karena adanya perbedaan penafsiran tentang standar kebenaran yang digunakannya. Kejahatan ini dianggap relatif, karena setiap orang dapat menafsirkan dari sudut yang berbeda.

Berdasarkan tinjauan kriminologi tersebut maka dapatlah ditentukan bahwa penganiayaan yang dilakukan suami terhadap istri dan anak di dalam rumah tangga ialah pelaku kejahatan itu (suami) terkadang tidak sengaja melakukan penganiayaan kepada istri dan anak, telah terbiasa melakukan penganiayaan kepada suami dan anaknya, ataupun suami menganggap perbuatannya itu adalah tidak salah dengan kata lain hal tersebut perbuatan yang benar. Pemikiran yang demikianlah yang terdapat pada sebagian besar kepala keluarga (suami) yang melakukan penganiayaan di dalam rumah tangga, sehingga pelaku kejahatan kriminologi (penganiayaan) itu tetap melakukan tindakan itu kepada istri dan anak. 
Paling diharapkan untuk menghindari penganiayaan yang dilakukan suami dalam rumah tangga adalah keterpaduan kerja sama antara ayah (suami) dan ibu (istri) dalam melakukan tugas ini. Jalinan kerja sama antara keduanya hanya akan dapat diwujudkan selama kedua orang tua itu masih tetap dalam hubungan suami istri yang baik. Dalam suasana yang demikian, kendatipun tugas itu sesuai dengan tabiatnya akan lebih banyak dilakukan oleh pihak ibu, tetapi peranan seorang ayah tidak dapat diabaikan, baik dalam memenuhi segala kebutuhan yang memperlancar tugas, maupun dalam menciptakan suasana dalam rumah tangga di mana anak diasuh dan dibesarkan (Satria Effendi, 2010: 166-167).

\section{F. Penutup}

Tinjauan kriminologi penganiayaan suami terhadap istri dan anak di dalam rumah tangga mengaitkan banyak hal. Unsur-unsur kriminologi itu ada unsur kesengajaan ataupun tidak, penganiayaan itu tetap termasuk kejahatan kriminologi apabila menimbulkan rasa sakit, tidak enak pada tubuh, lukanya tubuh (baik luka ringan atau luka berat), serta harus ada juga unsur perbuatan, baik berawal dari penyerangan ataupun perkelahian, dan jika semua hal ini terpenuhi pada saat suami melakukan penganiayaan kepada istri dan anaknya, maka lengkaplah unsur kejahatan kriminologi suami.

Berdasarkan kajian kriminologi pula ditemukan bahwa suami melakukan penganiayaan kepada istri dan anak kebanyakan karena sebelumnya telah melakukan kejahatan kriminologi yang lain, sehingga memicu melakukan penganiayaan kepada istri dan anak ketika sampai di rumah. Unsur kriminologi itu terbukti bahwa sebelumnya suami telah melakukan tindakan kejahatan yang lainnya, dan suami menjadi terbiasa melakukan kejahatan kriminologi itu, sehingga kejahatan kriminologi (penganiayaan) tersebut dapat dikelompokkan menjadi kejahatan penganiayaan ringan dan kejahatan penganiayaan berat. 


\section{DAFTAR PUSTAKA}

\section{Buku:}

Adami Chazawi. 2011. Penafsiran Hukum Pidana, Dasar Peniadaan, Pemberatan \& Peringanan, Kejahatan Aduan, Perbarengan \& Ajaran Kausalitas. Jakarta: Rajawali Pers.

Adami Chazawi. 2013. Kejahatan Terhadap Tubuh dan Nyawa. Jakarta: Rajawali Pers.

Bonger, W.A. 1995. Pengantar Tentang Kriminologi. Jakarta: Pustaka Sarjana,

Muhammad Ali. 2000. Kamus Lengkap Bahasa Indonesia Modern. Jakarta: Pustaka Amani.

Muhammad Yusuf Siregar. 2015. Hukum Perkawinan di Indonesia, Rantauprapat: Yayasan Universitas Labuhanbatu.

Mustofa Hasan. 2011. Pengantar Hukum Keluarga. Bandung: CV.Pustaka Setia.

Satria Effendi. 2010. Problematika Hukum Keluarga Islam Kontemporer, Jakarta: Kencana.

Soesilo, R. 1995. Kitab Undang-undang Hukum Pidana srta Komentarkomentarnya Lengkap Pasal Demi Pasal. Bogor: Politeia.

Topo Santoso dan Eva Achjani Zulfa. 2010. Kriminologi. Jakarta: Rajawali Pers.

\section{Peraturan Perudangan-undangan:}

Republik Indonesia, Undang-undang Nomor 1 Tahun 1946, tentang Peraturan Hukum Pidana.

Republik Indonesia, Undang-undang Nomor 1 Tahun 1974 tentang Perkawinan.

Republik Indonesia, Undang-undang Nomor 23 Tahun 2004 tentang Penghapusan Kekerasan Dalam Rumah Tangga.

Republik Indonesia, Undang-undang Nomor 35 Tahun 2014 tentang Perubahan Atas Undang-undang Republik Indonesia Nomor 23 Tahun 2002 tentang Perlindungan Anak. 


\section{BIODATA PENULIS}

$\begin{array}{ll}\text { Nama } & : \text { Lailatus Sururiyah, S.H., M.H } \\ \text { Pekerjaan } & : \text { Dosen Fakultas Hukum Universitas Muhammadiyah Sumatera } \\ & \text { Utara } \\ \text { Jabatan } & : \text { Asisten Ahli } \\ \text { Nomor HP } & : \text { 081361681589 } \\ \text { E-mail } & : \text { ailatussururiyah@gmail.com } \\ \text { Alamat Kantor } & : \text { Jl. Kapten Muchtar Basri No. 3, Medan }\end{array}$ 